\title{
Linkages between property asset returns and interest rates: evidence for the UK
}

Article

Accepted Version

Brooks, C. and Tsolacos, S. (2001) Linkages between property asset returns and interest rates: evidence for the UK. Applied Economics, 33 (6). pp. 711-719. ISSN 1466-4283 doi: https://doi.org/10.1080/00036840122812 Available at https://centaur.reading.ac.uk/35971/

It is advisable to refer to the publisher's version if you intend to cite from the work. See Guidance on citing.

Published version at: http://dx.doi.org/10.1080/00036840122812

To link to this article DOI: http://dx.doi.org/10.1080/00036840122812

Publisher: Taylor \& Francis

All outputs in CentAUR are protected by Intellectual Property Rights law, including copyright law. Copyright and IPR is retained by the creators or other copyright holders. Terms and conditions for use of this material are defined in the End User Agreement.

\section{www.reading.ac.uk/centaur}

\section{CentAUR}

Central Archive at the University of Reading

Reading's research outputs online 
This is an author's accepted manuscript of an article published in Applied Economics (2001) [copyright Taylor \& Francis], available online at: http://www.tandfonline.com/10.1080/00036840122812 


\title{
LINKAGES BETWEEN PROPERTY ASSET RETURNS AND INTEREST RATES: EVIDENCE FOR THE UK
}

\author{
Chris Brooks, Sotiris Tsolacos
}

1 April 1999

\begin{abstract}
This paper considers the effect of short- and long-term interest rates, and interest rate spreads upon real estate index returns in the UK. Using Johansen's vector autoregressive framework, we find that the real estate index cointegrates with the term spread, but not with the short or long rates themselves. Granger causality tests indicate that movements in short term interest rates and the spread cause movements in the returns series. However, decomposition of the forecast error variances from VAR models indicate that changes in these variables can only explain a small proportion of the overall variability of the returns, and that the effect has fully worked through after two months. Our results suggest that these financial variables could potentially be used as leading indicators for real estate markets, with corresponding implications for return predictability.
\end{abstract}

J.E.L. Classifications: C32, C52

Keywords: real estate returns, interest rates, term spreads, cointegration, Granger causality, VAR. 


\section{INTRODUCTION}

In the literature on real estate returns, authors have considered the predictive power of interest rates and interest rate spreads to explain the variation in returns on real estate-backed assets. The importance attached to interest rate variables originates from the substantive work on stock and bond returns which includes interest rates and spreads in the set of predetermined macroeconomic financial variables employed to explain their time series behaviour (relevant studies include Campbell, 1987; Fama and French, 1989; Breen et al, 1989; Ferson, 1989; Chen, 1991; Ferson and Harvey, 1991). Interest rates and interest rate spreads are considered to contain predictive information about asset return movements. The main reason for this link is the assumption that returns relate directly to the present and future state of the economy and business conditions, and these are in part governed by interest rates. For example Chen (1991) suggests that short-term interest rates fluctuate with economic conditions and Fama and French (1989) argue that short-term interest rates tend to be low in an economic slump and high at times of business expansion. Other theoretical intuition provides further justification to the economic relationship between interest rates and asset returns. Breen et al (1989) suggest that interest rates are good proxies for inflation which relates inversely to excess asset returns. According to Chen et al (1986), the influence of interest rates on stock returns works through the discount rate. Unanticipated changes in the riskless interest rate will influence equity pricing via the time value of future cash flows and hence returns.

Particular attention has been given to interest rate spreads or the term structure of interest rates. Changing spreads denote changes in the slope of the yield curve. It is submitted that the slope of the yield curve can provide a useful indicator of future cyclical output movements. Fama and French (1989) claim that interest rate spreads are closely related to the shorter term 
business cycle. Estrella and Hardouvelis (1991) argue that the slope of the yield curve can predict cumulative changes in real output for up to four years into the future. Similar arguments about the predictive ability of the spread are put forward by Chen (1991). Estrella and Hardouvelis (1991) explain that a current short-lived monetary tightening would increase the level of nominal interest rates but will have a relatively weaker effect on long-term rates, thus causing the yield curve to flatten. At the same time, current real interest rates are likely to increase (assuming price rigidities) resulting in low current investment activity and lower output in the immediate future. Both the current slope of the yield curve and the expected growth in output decline, resulting in a positive association between the two variables. Davis and Fagan (1997) provide evidence showing that the ability of the yield spread (and financial spreads in general) to predict output varies across countries. The yield curve can also be used to predict future spot rates. When the spread between long- and short-term rates widens, next period's long rate is expected to rise because of the expectation of higher spot rates in the future (Hardouvelis, 1994). However, some authors have expressed concerns over this expectations hypothesis (Campbell and Shiller, 1991; Bekaert et al, 1997). Finally, Laurent (1988) has argued that a widening in the term structure could positively influence economic activity since banks may increase the purchase of long-term securities and increase the amount of long-term loans.

The above discussion provides economic justification for the inclusion of interest rates and interest rate spreads in the study of the time series characteristics of real estate returns. Real estate returns are linked to the macroeconomy and business conditions (Ling and Naranjo 1997; Liu and Mei, 1992). Interest rates and spreads are considered predictors of economic activity. In their investigation of the sensitivity of real estate returns to macroeconomic innovations, Chan et al (1990) assume that the term structure is one of the factors that 
consistently drive real estate returns. Lizieri and Satchell (1997) expand on the links between commercial property markets and the real rate of interest, and argue that in conventional valuation methodologies, rents are capitalised using an initial yield which is dependent on nominal interest rates. As a result, the importance of interest rates and the slope of the yield curve in explaining the inter-temporal variation in real estate returns has been the subject of empirical research. The bulk of this work is in the context of the US market. A survey of existing studies reveals inconclusive results about the effect of interest rate variables on the time series behaviour of real estate returns. McCue and Kling (1994), using a VAR methodology, claim that interest rates have a very significant influence on equity real estate investment trust (REIT) returns net of stock market influences. The same results were obtained by Ling and Naranjo (1997), who used a multifactor asset pricing model and regression analysis to study the sensitivity of excess real estate returns (defined as the return in excess of the risk free rate) to a set of predetermined variables. Mueller and Pauley (1995) looked specifically at the effects of interest rates on REIT price changes. Their study did not establish significant effects on REIT prices originating in the movements of short- and longterm interest rates either in periods when interest rates are high or in periods of low interest rates. Chan et al (1990) examined excess returns within a multifactor APT framework and provided supporting evidence to the term structure as a predictive variable for movements in real estate market returns. On the other hand Liu and Mei (1992), who based their estimates on the multifactor model with time varying risk premiums, did not find such evidence. Ling and Naranjo (1997) found that the spread variable could become important in particular periods. In the UK, Lizieri and Satchell (1997) adopted a threshold autoregressive methodology and established a significant non-linear relationship between the real rate of interest and property company stock prices. It was also found that this relationship was sensitive to high interest and low interest rate regimes. 
It can be argued, of course, that the results obtained in the current literature depend to a degree on the methodology used and on the sample periods investigated. Although this is a possible reason for the inconclusive findings, it appears that the role of interest rate variables in the inter-temporal variation in the returns of real estate backed assets needs further investigation and evidence from international markets.

The overall objective of the present study is to provide additional evidence on the significance of interest rates and interest rate spreads on property company returns with the use of UK data. This relationship is explored empirically over both the short- and long-run. Existing work has not examined the possibility of long-run relationships between interest rate variables and property returns. The presence of equilibrium conditions that keeps returns and interest rates in proportion to each other in the long-run has implications for the study of the time series behaviour of the former. The short-run analysis of the relationship between interest rates and returns particularly aims to investigate causality between returns and interest rates and to establish the magnitude of the proportion of the variation in property company returns which is attributable to movements in interest rates and the changing slope of the yield curve. This study concludes that property company returns and the interest rate spread exhibit a long-run relationship. Long-term interest rates do not appear, however, to cause variation in returns. It is also found that the contribution of the short-term interest rate and interest rate spread to the variation in property company returns in the UK is not significant. Therefore, attention should be given to other macroeconomic influences which theory suggests may affect real estate asset price movements. 
The remainder of the paper is organised in three sections. Section 2 outlines the methodology employed in this study, and describes the data. In section 3, the empirical findings are reported. Section 4 summarises the results in the context of the existing literature and discusses the implications for the predictability of property-backed asset returns.

\section{METHODOLOGY AND DATA}

The first step in the empirical investigation of the relationship between property company returns, interest rates and the interest rate spread is to establish whether these variables move together over the long-run. Theory suggests that property returns adjust to changing business conditions and that interest rates and the spread vary with economic trends. Therefore, if these variables form a long-run equilibrium relationship and cointegrate, a combination of them will be stable (and stationary) even though the series contain stochastic trends. Short-run disequilibrium situations may occur, but they will be corrected and the system will eventually revert back to its long-run equilibrium path. In most existing studies, the possibility of a longrun relationship between real estate returns and the pre-specified variables considered has not been investigated. This may result in two methodological problems when the a priori relationships are examined in the short-run. First, if the variables are cointegrated, important long-run information can be omitted. Second, the presence of non-stationary variables which do not form cointegrating vectors and which are not suitably transformed to induce stationarity in these methodologies could lead to spurious results. The advantage of using cointegration analysis is the ability to incorporate short-term dynamic elements with long-run equilibrium relations among variables. The Durbin-Watson (D-W) statistic, the Engle and Granger (1987) procedure and the Johansen maximum likelihood framework (Johansen, 1988, 1991; Johansen and Juselius, 1990) are used to conduct the cointegration analysis. The former two techniques examine the stationarity of the residuals of the cointegration equations. 
The latter technique, which is considered more powerful (Gonzalo, 1994), identifies cointegrating relationships within an error correction VAR model by applying a maximum likelihood estimation technique.

Following an investigation of long-run relationships in the set of variables, Granger (1969) causality tests are performed between the series using bivariate VAR systems. We test two null hypotheses, namely that of : (i) zero coefficients on lagged interest rates and the term structure in the equation of returns which includes lagged terms of all variables and (ii) zero coefficients on lagged property returns in the equations of interest rates and interest rate spreads, which also include own lags. Granger causality is not established in either direction if the lagged coefficients of the relevant explanatory variables are all not significantly different from zero in both equations. Finally, the issue of the magnitude of the variation in property company returns attributable to the interest rate variables is examined. Variance decompositions are computed from the specified unrestricted and error correction representations of the bivariate VAR models ${ }^{1}$.

Data for property returns are obtained from Datastream International. The data comprises a market value-weighted index constructed by Datastream, based upon the top 26 property stocks traded on the London Stock Exchange. The relative weightings given to the component stocks are updated on a monthly basis. Two interest rates are used: a short-term rate and a long-term rate. The short-term interest rate is the three month end of period Treasury Bill rate. The long-term rate is the period average redemption yield on 20 year government bonds in the UK (20 year gilts). The source for both series is also Datastream International. The definition of the spread follows that in the current literature, which is the yield on 20 year gilts minus the one month Treasury bill rate. The data used in this study are monthly and cover the period 
January 1968 to April 1998, giving a total of 375 observations; the series are transformed to their logarithms, with these being employed for all subsequent analysis. The following abbreviations for the variables are used: $P R O P R$ refers to property company returns; $T B I L$ is the Treasury Bill rates; YG20 is the yield on 20 year gilts and SPRE is the interest rate spread defined above.

\section{EMPIRICAL RESULTS}

Summary statistics for the variables are given in Table 1. It is evident that all variables except SPRE have unconditional distributions which are non-normal, this result being predominantly due to the coefficient of kurtosis rather than skewness.

Table 1 . Summary statistics

\begin{tabular}{|lcccc|}
\hline & $P R O P R$ & TBIL & YG20 & SPRE \\
\hline Mean & 7.27 & 2.18 & 2.32 & 0.14 \\
Standard deviation & 1.18 & 0.33 & 0.23 & 0.24 \\
Skewness & -0.10 & -0.20 & 0.11 & 0.15 \\
Kurtosis & 1.67 & 2.05 & 2.37 & 2.92 \\
Jarque-Bera normality & 27.39 & 15.92 & 6.80 & 1.54 \\
test $(p$-value) & $(0.00)$ & $(0.00)$ & $(0.03)$ & $(0.46)$ \\
\hline
\end{tabular}

Prior to testing for possible long-run relationships in the group, the cointegrating properties of the variables need to be established. Cointegration requires each non-stationary series to be of the same order of integration. We therefore apply the augmented Dickey-Fuller (ADF) procedure and test the null hypothesis a unit root in the series. The ADF tests were applied both to the levels and the first differences of the series. Denoting the series under investigation (PROPR, TBIL, YG20 or SPRE) as $y_{t}$, then the ADF test centres around the calculation of the t-ratio on the lagged log-levels term, $y_{t-1}$ : 


$$
\Delta y_{t}=\mu+\phi y_{t-1}+\sum_{j=1}^{p} \Delta y_{t-j}+\varepsilon_{t}
$$

The null hypothesis of a unit root is rejected if the t-ratio is more negative than the critical value. The ADF representations were estimated with an intercept and the lag lengths were chosen on the basis of the Akaike Information Criterion (AIC) (Akaike, 1974). Table 2 reports the computed statistics. It appears that the ADF tests do not establish stationarity for the levels of any of the series at the five per cent level of significance. On the other hand, first differencing attains stationarity for all series at the one per cent level of significance. Therefore, all log-levels variables show the same degree of integration (I(1)) and the analysis proceeds to test for cointegrating relationships among the variables.

Table 2 - Augmented Dickey-Fuller tests for stationarity

\begin{tabular}{|lcc|}
\hline Variable & Level & First differences \\
\hline PROPR & -0.69 & $-13.65^{*}$ \\
TBIL & -2.35 & $-12.30^{*}$ \\
YG20 & -1.14 & $-12.36^{*}$ \\
SPRE & -2.67 & $-14.03^{*}$ \\
\hline
\end{tabular}

Note: $*$ denotes that the null hypothesis of a unit root is rejected at $1 \%$ significance level

Cointegrating regressions of the property company returns series against the Treasury Bill rate, the yield on 20 year gilts and the interest rate spread are carried out. One method of testing for cointegration is to investigate the stationarity or otherwise of the residuals of the individual cointegration equations. The stationarity of the residuals is tested because if the returns and the interest rate variables cointegrate, then a linear combination of the two series should be stationary. Two residual based tests of cointegration are used. The first test is a Durbin Watson test, according to which a statistic (known as the cointegrating regression Durbin Watson) close to 0 suggests that the residuals of the cointegrating regression are a 
random walk and are therefore non-stationary. This is an indication of no cointegration. The second test is to perform Dickey-Fuller tests on the residual series. The results form these two tests are shown in Table 3. The Durbin-Watson statistic for all variables appears to be very close to zero. The exception could arguably be the Durbin-Watson value in the last cointegrating equation, but it is still smaller than the critical value at the 5 per cent significance level.

ADF tests on the residuals produce somewhat different results. The ADF on the residuals of the first set of regressions (PROPR on TBIL and TBIL on PROPR) show that we cannot reject the null hypothesis of non-stationarity in the residuals at the 5 per cent level. However, stationarity is established in the residuals of the cointegrating regression of PROPR on YG2O but not in the residuals of the regression of $Y G 20$ on PROPR. A similar situation emerges with the cointegrating regressions PROPR on SPRE and SPRE on PROPR. Given that there is a degree of inconsistency in the results obtained from these residual-based cointegration tests, the Johansen maximum likelihood procedure is also deployed to strengthen the decision about rejecting or not rejecting cointegration among the variables in the group.

Table 3 - Cointegrating regressions and Engle and Granger cointegration tests

\begin{tabular}{|c|c|c|c|c|c|c|c|c|}
\hline \multirow{2}{*}{$\begin{array}{l}\text { Dependent } \\
\text { Variable }\end{array}$} & \multirow[t]{2}{*}{ Constant } & \multicolumn{4}{|c|}{ Coefficient of } & \multirow[t]{2}{*}{$\operatorname{Adj} . R^{2}$} & \multirow{2}{*}{$\begin{array}{c}\mathrm{D}-\mathrm{W} \\
\text { statistic }\end{array}$} & \multirow[t]{2}{*}{$\mathrm{ADF}$} \\
\hline & & PROPR & TBIL & $Y G 20$ & SPRE & & & \\
\hline PROPR & 7.66 & - & -0.18 & - & - & 0.00 & 0.00 & -0.77 \\
\hline$T B I L$ & 2.29 & -0.01 & - & - & - & 0.00 & 0.05 & -2.36 \\
\hline PROPR & 12.70 & - & - & -2.33 & - & 0.20 & 0.01 & $-3.11 *$ \\
\hline$Y G 20$ & 2.95 & -0.09 & - & - & - & 0.20 & 0.03 & -2.40 \\
\hline$P R O P R$ & 7.52 & - & - & - & -1.72 & 0.12 & 0.02 & -1.96 \\
\hline SPRE & 0.67 & -0.07 & - & - & - & 0.12 & 0.11 & $-3.15^{*}$ \\
\hline
\end{tabular}


Note: * denotes the rejection of the null hypothesis of non-stationary residuals at the 5 per cent level

The procedure suggested by Johansen aims to identify all distinct cointegrating relationships which exist within a group of variables via estimation of the cointegrating rank of a matrix $\Pi$, to be defined below. If there are $N$ endogenous variables each integrated of order one, there can be from zero to $N-1$ linearly independent cointegrating relations. In the present case, since we have only two variables in each set (we use pairwise regressions of the property index with each potential explanatory variable), one cointegrating equation at most can be established. Therefore, using the trace statistic we intially test the null hypothesis of zero cointegrating vectors in each pair of variables. Following Dimelis (1997), if this hypothesis is rejected, we test the null of one cointegrating vector. The trace test statistic is calculated as

$$
\lambda_{\text {trace }}=-T \sum_{i=r+1}^{N} \ln \left(1-\hat{\lambda}_{i}\right)
$$

where $T$ is the number of observations, and $r$ is the number of cointegrating vectors under the null hypothesis. $\hat{\lambda}_{i}$ are the ordered estimated eigenvalues of the $N \times N$ matrix $\Pi$, estimated using maximum likelihood in the following VAR

$$
\Delta y_{t}=\Gamma_{0}+\Pi y_{t-p}+\sum_{i=1}^{p-1} \Gamma_{i} \Delta y_{t-i}+\varepsilon_{t}
$$

$y_{t}$ is an $N \times 1$ vector of potentially cointegrating variables, $\varepsilon_{t}$ is an $N \times 1$ vector of disturbance terms, $\Gamma_{0}, \Gamma_{1}, \ldots, \Gamma_{\mathrm{p}-1}, \Pi$ are all $N \times N$ coefficient matrices. The Johansen cointegration test has several variations to accommodate the deterministic trends in the variables and the cointegration equation. In addition, the test can be performed with or without means in the series and intercepts in the cointegration equations. In implementing the test here, two of the most common cases are treated with respect to means and deterministic trends. First, a test which allows for linear deterministic trend in data and intercept but no trend in the 
cointegrating equations. The second case is similar to the previous one, but it also allows for a trend in the cointegrating equations. The latter case is less restrictive.

The results of the Johansen test are given in Table 4. The likelihood ratio statistics have been estimated for the two different null hypotheses, of no cointegration $(r=0)$ and at most one cointegrating equation $(r \leq 1)$, under the test assumptions of trend and absence of trend in the cointegrating equations. In the first case (linear deterministic trend in the data and intercept but no trend in the cointegrating equations), the estimated likelihood ratios suggest that the null hypotheses ( $r=0$ and $r \leq 1)$ cannot be rejected. Thus cointegrating relationships are not identified. When a trend is allowed for in the cointegrating equations, the results obtained for $P R O P R$ and TBIL and PROPR and YG2O are similar but they differ for PROPR and SPRE. In the latter case, the null hypothesis $r=0$ is rejected in favour of cointegration whereas the null $r$ $\leq 1$ is not rejected. When the Johansen test is run under two alternative test assumptions namely no deterministic trend in the data series and no trend or intercept in the cointegrating equations, and no deterministic trend in the data series and no trend but intercept in the cointegrating equations - the likelihood ratios indicated one cointegrating equation at the five per cent significance level only for the group PROPR and SPRE. With regard to PROPR and SPRE, both the ADF test on the residuals of the cointegrating equation and the Johansen test under three different test assumptions provide evidence of cointegration. Thus it appears that these two variables exhibit an equilibrium relationship and move in proportion over the longrun. This is of course not the dynamics that describe the relationship of PROPR with TBIL and PROPR with SPRE.

Table 4 . Johansen cointegration tests 


\begin{tabular}{|lcccc|}
\hline & \multicolumn{2}{c|}{$\begin{array}{c}\text { Without a trend in } \\
\text { cointegrating equations }\end{array}$} & \multicolumn{2}{c|}{$\begin{array}{c}\text { With a trend in } \\
\text { cointegrating equations }\end{array}$} \\
\hline Series & $\mathrm{H}_{0}: r=0$ & $\mathrm{H}_{0}: r \leq 1$ & $\mathrm{H}_{0}: r=0$ & $\mathrm{H}_{0}: r \leq 1$ \\
PROPR, TBIL & 9.95 & 0.30 & 24.08 & 8.16 \\
PROPR, YG20 & 10.91 & 0.13 & 21.77 & 8.60 \\
PROPR, SPRE & 14.56 & 1.06 & $30.32 *$ & 8.90 \\
\hline 5\% critical value & 15.41 & 3.76 & 25.32 & 12.25 \\
\hline$r$ indicates numbers of cointegrating relationships & & \\
\hline
\end{tabular}

Note: * indicates significance at the $5 \%$ level.

The information produced by the cointegration analysis guides the formulation of the VAR models used in the next part of the study to examine causality and the impact of interest rates and the term structure or spread on property returns. Since the findings above indicated that property returns and both the Treasury Bill rate and the yield on 20 year gilts have no longrun equilibrium relationship, an unconstrained VAR is estimated. The statistics in Table 2 suggest that a VAR in first differences is appropriate (variables in differences are signified by the first difference operator $\Delta$ ). The VAR models can be expressed as

$$
\left[\begin{array}{c}
\Delta \text { PROPR }_{t} \\
\Delta \text { TBIL }_{t}
\end{array}\right]=\left[\begin{array}{c}
\alpha_{0} \\
\alpha_{1}
\end{array}\right]+\sum_{i=1}^{p}\left[\begin{array}{ll}
\beta_{i 00} & \beta_{i 01} \\
\beta_{i 10} & \beta_{i 11}
\end{array}\right]\left[\begin{array}{c}
\Delta P R O P R_{t-i} \\
\Delta \text { TBIL }_{t-i}
\end{array}\right]+\left[\begin{array}{c}
\varepsilon_{1 t} \\
\varepsilon_{2 t}
\end{array}\right]
$$

and

$$
\left[\begin{array}{c}
\Delta P R O P R_{t} \\
\Delta Y G_{t}
\end{array}\right]=\left[\begin{array}{c}
\alpha_{0} \\
\alpha_{1}
\end{array}\right]+\sum_{i=1}^{p}\left[\begin{array}{ll}
\beta_{i 00} & \beta_{i 01} \\
\beta_{i 10} & \beta_{i 11}
\end{array}\right]\left[\begin{array}{c}
\Delta P R O P R_{t-i} \\
\Delta Y G_{t-i}
\end{array}\right]+\left[\begin{array}{c}
\varepsilon_{1 t} \\
\varepsilon_{2 t}
\end{array}\right]
$$

where $p$ is the number of lags of each term in each equation (in this case, 2,4,6,8, or 12). Causality is tested within Granger's framework using bivariate VAR systems. The Granger causality test that $\triangle P R O P R$ does not cause $\triangle T B I L$ is a test of the joint null hypothesis that $\beta_{\mathrm{i} 01}$ $=0 \forall i$ against a two-sided alternative. That $\triangle T B I L$ does not cause $\triangle P R O P R$ is tested using the null that $\beta_{\mathrm{i} 10}=0 \forall i$, and so on. 
In the case of the one cointegrating relationship identified for property returns and the spread, an error correction representation of a VAR model (a vector error correction (VECM) model) is constructed, and this is econometrically valid since all components of the VECM model will be stationary. The VECM model is given by $\left[\begin{array}{c}\Delta P R O P R_{t} \\ \Delta S P R E_{t}\end{array}\right]=\left[\begin{array}{c}\alpha_{0} \\ \alpha_{1}\end{array}\right]+\sum_{i=1}^{p}\left[\begin{array}{cc}\beta_{i 00} & \beta_{i 01} \\ \beta_{i 10} & \beta_{i 11}\end{array}\right]\left[\begin{array}{c}\Delta P R O P R_{t-i} \\ \Delta S P R E_{t-i}\end{array}\right]+\left[\begin{array}{c}\gamma_{0} \\ \gamma_{1}\end{array}\right]\left[\begin{array}{c}L P R O P_{t-1}-\hat{\delta}_{00}-\hat{\delta}_{01} L S P R E_{t-1} \\ L P R O P_{t-1}-\hat{\delta}_{10}-\hat{\delta}_{11} L S P R E_{t-1}\end{array}\right]+\left[\begin{array}{c}\varepsilon_{1 t} \\ \varepsilon_{2 t}\end{array}\right]$

The causality tests still constitute the null hypotheses involving the relevant betas as above, but in this case we are allowing for the long run relationship which has been found to exist between the variables. The results are given in Table $5^{2}$. In this table the computed $F$ statistics are shown along with the critical values. Since it is the convention to test the sensitivity of the results over different periods, we did so for lag lengths of $2,4,6,8$ and 12 periods. Table 5 shows the results for only 4 and 8 lagged periods but the findings were not qualitatively different when other lag lengths were used. According to the results, the null hypothesis of $\triangle T B I L$ not Granger causing $\triangle P R O P R$ is rejected at the five per cent significance level. The opposite null hypothesis is not rejected. The results for $\triangle P R O P R$ and $\triangle Y G 20$ show that it is only the former variable that Granger causes the latter. Thus changes in short term interest rates appear to cause changes in the property index, and help to predict it, unlike changes in long term interest rates. Finally, a two directional relationship is established for property returns and the spread of interest rates when the number of lags is 4 . However, when the number of lags increases to 8 , the causal relationship becomes unidirectional running from $\triangle S P R E$ to $\triangle P R O P R$. Estimations with different numbers of lags show that causality running from $\triangle P R O P R$ to $\triangle S P R E$ is sensitive to the lag length unlike the consistent evidence of causality running in the opposite direction. It is therefore concluded from the 
Granger causality analysis that it is only $\triangle T B I L$ and $\triangle S P R E$ that Granger cause or precede the variation in $P R O P R$.

Table 5 a Tests of causality between the variables

\begin{tabular}{|lcc|}
\hline & Lags: 4 & Lags: 8 \\
\hline$\triangle P R O P R$ does not cause $\triangle T B I L$ & $11.17^{*}$ & $6.83^{*}$ \\
$\triangle T B I L$ does not cause $\triangle P R O P R$ & 0.48 & 1.21 \\
$\triangle P R O P R$ does not cause $\triangle Y G 20$ & 0.54 & 0.57 \\
$\triangle Y G 20$ does not cause $\triangle P R O P R$ & $4.01^{*}$ & $2.59^{*}$ \\
$\triangle P R O P R$ does not cause $\triangle S P R E$ & $10.44^{*}$ & $6.82^{*}$ \\
$\triangle S P R E$ does not cause $\triangle P R O P R$ & $3.03^{*}$ & 0.32 \\
\hline Critical $F$-values at 5\% & $F(4,350)=2.37$ & $F(8,338)=1.94$ \\
\hline
\end{tabular}

Note: $*$ denotes singnificance at the $5 \%$ level.

Since the Granger causality tests did not indicate any significance of lagged values of $\triangle Y G 20$ on $\triangle P R O P R$, the analysis proceeds to obtain further information on the predictability of property company returns in the UK with an examination of the influence of the three month Treasury bill rate and the spread between the average yield the 20 year gilts and the Treasury Bill rate. Based on an unrestricted VAR to describe the dynamic relation of $\triangle P R O P R$ and $\triangle$ $T B I L$, and a vector error correction model for PROPR and SPRE is constructed, and the forecast error decompositions are calculated. The lag lengths were again determined by AIC. Table 6 provides the results of the variance decompositions for two different orderings since the decomposition of variance can depend critically on the ordering of the variables in the VAR. For a forecast horizon of 12 months, it is clear that $\triangle T B I L$ can only explain about 10 per cent of the forecast variance of $\triangle P R O P R$. Most of this variance is explained by the own innovations of the return series. It can also be observed that reordering the variables does not 
affect the results. The findings generated by the vector error correction model describing the relationship between real estate returns and the interest rate spread are very similar. Even after 12 months, the spread variable can only explain about 8.4 per cent of the forecast error variance. Again, innovations in the returns series itself explain most of the forecast error variance. The results do not alter when the order of the variables in the error correction VAR reverses. 
Table 6 - Variance decompositions for property company returns

\begin{tabular}{|c|c|c|c|c|c|c|c|c|}
\hline \multirow[b]{2}{*}{$\begin{array}{c}\text { Months } \\
\text { ahead }\end{array}$} & \multicolumn{4}{|c|}{$\begin{array}{c}\triangle P R O P R \text { explained by innovations in: } \\
\qquad P R O P R \text { and } \triangle T B I L\end{array}$} & \multicolumn{4}{|c|}{$\begin{array}{c}P R O P R \text { explained by innovations in: } \\
\text { PROPR and SPRE }\end{array}$} \\
\hline & \multicolumn{2}{|c|}{$\begin{array}{c}\text { Order I } \\
\triangle P R O P R, \triangle T B I L\end{array}$} & \multicolumn{2}{|c|}{$\begin{array}{c}\text { Order II } \\
\triangle T B I L, \triangle P R O P R\end{array}$} & \multicolumn{2}{|c|}{$\begin{array}{c}\text { Order I } \\
P R O P R, S P R E\end{array}$} & \multicolumn{2}{|c|}{$\begin{array}{c}\text { Order II } \\
\text { SPRE, PROPR }\end{array}$} \\
\hline & $\triangle P R O P R$ & $\triangle T B I L$ & $\triangle P R O P R$ & $\triangle T B I L$ & PROPR & SPRE & PROPR & SPRE \\
\hline 1 & 100.0 & 0.0 & 99.4 & 0.6 & 100.0 & 0.0 & 100.0 & 0.0 \\
\hline 2 & 90.3 & 9.7 & 89.1 & 10.9 & 96.1 & 3.9 & 96.4 & 3.6 \\
\hline 3 & 90.2 & 9.8 & 88.9 & 11.1 & 95.5 & 4.5 & 95.6 & 4.1 \\
\hline 4 & 90.1 & 9.9 & 88.8 & 11.2 & 95.2 & 4.8 & 95.6 & 4.4 \\
\hline 5 & 90.1 & 9.9 & 88.8 & 11.2 & 94.8 & 5.2 & 95.2 & 4.8 \\
\hline 6 & 90.1 & 9.9 & 88.8 & 11.2 & 94.3 & 5.7 & 94.8 & 5.2 \\
\hline 7 & 90.1 & 9.9 & 88.8 & 11.2 & 93.9 & 6.1 & 94.4 & 5.6 \\
\hline 8 & 90.1 & 9.9 & 88.8 & 11.2 & 93.4 & 6.6 & 93.9 & 6.1 \\
\hline 9 & 90.1 & 9.9 & 88.8 & 11.2 & 93.0 & 7.0 & 93.5 & 6.5 \\
\hline 10 & 90.1 & 9.9 & 88.8 & 11.2 & 92.5 & 7.5 & 93.0 & 7.0 \\
\hline 11 & 90.1 & 9.9 & 88.8 & 11.2 & 92.0 & 8.0 & 92.6 & 7.4 \\
\hline 12 & 90.1 & 9.9 & 88.8 & 11.2 & 91.6 & 8.4 & 92.2 & 7.8 \\
\hline
\end{tabular}

\section{CONCLUSIONS}

Investment in real estate backed assets represents a significantly growing trend in the UK investment market. This movement towards public vehicles in real estate investment has been even more notable in the US, where the real estate investment trust market and the commercial mortgage-backed securities market have doubled in size over the last two years. Similar trends can be observed in continental Europe, although this type of investment is still in its infancy in most countries. Given the growing significance of public real estate vehicles for investment and portfolio diversification purposes, several authors have undertaken work to investigate the predictability of returns on real estate-backed securities. This work is along the lines of the literature studying the movements of stock and bond prices. Researchers have 
included interest rates and interest rate spreads in the set of pre-specified macroeconomic and financial variables employed in their studies of the predictability of asset price movements. It is assumed that interest rates and interest rate spreads vary with economic activity and are predictors of future output, inflation rates and future spot interest rates which affect asset returns. Interest rates and interest rate spreads are favoured by researchers because they are immediately observable and offer the advantage of adjusting quickly to economic conditions and inflation trends, unlike other economic data which are made available with a delay and are subject to revisions (Davis and Fagan, 1997).

The impact of interest rates and spreads on returns and their usefulness in the predictability of property asset price movements have yet to be established. Findings from existing studies are contradictory. A number of authors have argued that interest rate variables convey information about the predictability of returns, whereas others have found weak or no evidence of such economic relationships. It can be argued that the results of individual studies are influenced by the methodology deployed and the alternative real estate return series used, which include actual property returns, excess returns (returns over the risk-free rate) or property returns net of stock market influences. Despite this source of possible conflict in the results, the existing findings warrant further research on this subject.

The present paper provides a study of the relationship of property company returns in the UK with three interest rate variables: the three month Treasury Bill rate as a proxy for short-term interest rates, the average yield on 20 year gilts as a measure of long-term interest rates and the interest rate spread defined as the difference between the average yield on 20 year gilts and the three month Treasury Bill rate. Initially, the anticipated relationship and the indicator properties of these variables are examined over the long-run within a framework of 
cointegration analysis. Cointegration tests indicate that the spread variable cointegrates with the Datastream International property company return series we use. Therefore, although these variables are individually random walks which means that the effects of temporary shocks tend to be permanent, they appear to move in proportion in the long run. Any deviation from the equilibrium path will be transitory. The finding that property company returns and the spread between the long-run and the short-run rates move in line in the longrun implies that: (i) price movements of real estate assets enhance expected economic conditions and hence anticipated returns and (ii) the spread reflects the market's expectations about future economic activity. It can therefore be argued that analysts and traders in the real estate investment market incorporate the information conveyed by the slope of the yield curve and that they therefore value property company stocks rationally. Rational valuation of these stocks requires that their price embodies the expected performance of the underlying direct real estate investment market. The performance of the property sector and its income generating ability (e.g. rents and capital growth) are linked to future trends in the economy, captured by the interest rate spread. Our estimates did not identify any long-run relationships between property company returns and the short- or long-term interest rates. This implies that in the short-run, these variables can influence property returns, but this impact is not proportional over the long-run to establish a cointegrating relationship.

Granger causality tests confirmed causal relationships from both the Treasury Bill rate and the spread variables to the return series. The average 20 year gilt yield did not appear to cause variation in property company returns. This may suggest that investors do not consider the variation in long-term interest rates a strong indicator of monetary policy and predictor of returns on real estate assets. Thus it is inferred on the basis of these findings that changes in the Treasury Bill rate and the interest rate spread precede the variation in property asset 
returns in the UK and can be used as leading indicators. This is in accordance with the results obtained from two recent UK studies (Lizieri and Satchell, 1997). The significance of this causal relationship was examined by decomposing the variance of the property returns forecast error obtained from a VAR and a vector error correction model (the latter was used for the cointegrating variables). It was found that in a forecast horizon of twelve months, the Treasury Bill rate and the interest rate spread individually do not explain more than ten per cent of the forecast error variance of property company returns. This leaves a significant part of property return variation unexplained. The VAR estimates also showed that the information in the Treasury Bill rate and the spread is assimilated in asset prices within two months. It is arguable whether this time horizon indicates an informationally efficient market. It is expected that in an efficient market, information contained in any economic or financial variables is incorporated swiftly. Long periods of assimilation are deemed as evidence of market inefficiencies (McCue and Kling, 1994). McCue and Kling have argued that in the US, REIT returns adjust with a lag to pre-specified variables (the lag could be over twelve months) suggesting an informationally inefficient stock market which can potentially give rise to profitable opportunities.

Although a significant impact on returns from the variation in the Treasury Bill rate and the interest rate spread was not documented, we found that the relationship between the Treasury Bill rate and returns is negative which conforms to a priori expectations. The relationship between the spread and returns is positive. This sign can be explained on the basis of the Estrella and Hardouvelis (1991) argument. An increase in the spread between long- and shortterm rates could be the result of a monetary expansion. Current rates are reduced but longterm rates are not affected as much by the future inflationary expectations based on the current expansionary monetary policy. Another plausible explanation of this result is that 
although short-term interest rates have fallen, the markets expect them eventually to rise. Thus if we consider that the expectations hypothesis posits that long term interest rates should be an average of current and future expected short rates, and that the latter are lower than the former, then the long rate will be less affected. The increase in the spread is associated with a rise in the level of investment, consumption and output, both in the current period and in the immediate future. These expectations about the macroeconomy are reflected in the anticipated returns on property assets through the expected performance of the underlying property market.

Overall, the present study suggests that the predictability of property company returns is a subject area requiring further research. Information contained in additional economic and financial variables should be utilised for this purpose. It is important, however, that evidence from international markets is produced since existing findings have not documented the influence of a standard set of variables on property equity returns. This evidence would be helpful for analysts in order to identify the variables which predict or do not predict real estate backed asset returns and to examine whether the risk originating in these variables is priced.

Chris Brooks, ISMA Centre, Department of Economics, PO Box 242, The University of Reading, Whiteknights, Reading RG6 6BA; e-mail: C.Brooks@ reading.ac.uk

Sotiris Tsolacos, Centre for Spatial and Real Estate Economics, Department of Economics, University of Reading 


\section{REFERENCES}

Akaike, H.(1974) A New Look at the Statistical Model Identification IEEE Transactions on Automatic Control Vol: AC-19(6), pp. 716-723.

Bekaert, G., R.J.Hodrick and D.A.Marshall (1997). On Biases in Tests of the Expectations Hypothesis of the Term Structure of Interest Rates. Journal of Financial Economics Vol. 44, pp. 309-348.

Breen, W., Glosten, L.R. and Jagannathan, R. (1989). Economic Significance of Predictable Variations in Stock Index Returns. Journal of Finance Vol. 44(5), pp. 1177-1189.

Campbell, J.Y (1987). Stock Returns and the Term Structure. Journal of Financial Economics Vol. 18(2), pp. 373-399.

Campbell, J.Y. and Shiller, R.J (1991). Yield Spreads and Interest Rate Movements: A Bird'sEye View. Review of Economic Studies Vol. 58, pp. 495-514.

Chan, K.C., Hendershott, P.H. and Sanders, A.B. (1990) Risk and return on real estate: evidence from equity REITs, American Real Estate and Urban Economics Association Journal Vol. 18, pp. 431-52.

Chen, N-F (1991). Financial Investment Opportunities and the Macroeconomy. Journal of Finance Vol. 46(2), pp. 529-554.

Chen, N-F., Roll, R. and Ross, S.A. (1986). Economic Forces and the Stock Market. Journal of Business Vol. 59(3), pp. 383-403.

Davis, E.P. and Fagan, G. (1997). Are Financial Spreads Useful Indicators of Future Inflation and Output Growth in EU Countries?. Journal of Applied Econometrics Vol. 12, pp. 701-714.

Dimelis, S.A. (1997). Cyclical and Causal Relations between Real Wages and Employment in the EU Applied Economics Vol. 29, pp. 311-324.

Engle, R.F. and Granger, C.W.J. (1987). Cointegration and Error Correction: Representation, Estimation and Testing. Econometrica Vol. 55, pp. 251-276.

Estrella, A. and Hardouvelis, G.A. (1991). The Term Structure as a Predictor of Real Economic Activity. Journal of Finance Vol. 46(2), pp. 555-576

Fama, E. and French, K. (1989). Business Conditions and Expected Returns on Stocks and Bonds. Journal of Financial Economics Vol. 25, pp. 23-49.

Ferson, W.E (1989). Changes in Expected Security Returns, Risk, and Level of Interest Rates. Journal of Finance Vol. 44, pp. 1191-1217.

Ferson, W.E. and Harvey, C.R. (1991). The Variation of Economic Risk Premiums. Journal of Political Economy Vol. 99(2), pp. 385-415.

Gonzalo, L (1994). Five Alternative Methods of Estimating Long-run Equilibrium Relationships. Journal of Econometrics Vol. 60, pp. 203-233. 
Granger, C.W.J (1969). Investigating Causal Relations by Econometrics Models and Cross-Sectional Methods. Econometrica Vol. 37, pp. 424-438.

Hardouvelis, G.A (1994). The Term Structure Spread and Future Changes in Long and Short Rates in the G7 Countries. Journal of Monetary Economics Vol. 33, pp. 255-283.

Johansen, S. (1991). Estimation and Hypothesis Testing of Cointegration Vectors in Gaussian Vector Autoregressive Models. Econometrica Vol. 59, pp. 1551-1580.

Johansen, S. (1988). Statistical Analysis of Cointegrating Vectors. Journal of Economic Dynamics and Control Vol. 12, pp. 231-254.

Johansen, S. and Juselius, K. (1990). Maximum Likelihood Estimation and Inference on Cointegration - With Applications to the Demand for Money. Oxford Bulletin of Economics and Statistics Vol. 52, pp. 169-210.

Laurent, R.D (1988). An Interest-Based Indicator of Monetary Policy. Economic Perspective. Federal Reserve Bank of Chicago, January/February: pp. 3-14.

Ling, D. and Naranjo, A. (1997). Economic risk factors and commercial real estate returns, Journal of Real Estate Finance and Economics Vol. 14(3), pp. 283-307.

Liu, C.H. and Mei, J. (1992). The predictability of returns on equity REITs and their co-movement with other assets, Journal of Real Estate Finance and Economics Vol. 5, pp. 401-18.

Lizieri, C. and Satchell, S. (1997). Property company performance and real interest rates: a regime switching approach, Journal of Property Research Vol. 14, pp. 85-97.

Mueller, G. and Pauley, K. (1995). The effect of interest-rate movements on real estate investment trusts, Journal of Real Estate Research Vol. 10(5), pp. 319-25.

McCue, T.E. and Kling, J.L. (1994). Real Estate Returns and the Macroeconomy: Some Empirical Evidence from Real Estate Investment Trust Data, 1972-1991 Journal of Real Estate Research Vol. 9(3), pp. 277-287.

\footnotetext{
${ }^{1}$ Impulse response functions were also computed and plotted, but gave a very similar picture to the variance decompositions. Hence the former are not shown due to space constraints, but are available upon request from the authors.

${ }^{2}$ The estimated coefficients for the VARs and the VECM are again not shown due to space constraints, since the formulation of these appropriate models was not an end in itself, but rather as a precursor to causality testing.
} 